\title{
Analyzing the Mutations of NOTCH1 and SF3B1 Genes in Cases with CLL Detected Isolated 13q Deletion
}

\author{
İzole 13q Delesyonu Saptanan KLL Olgularında NOTCH1 ve SF3B1 Genlerinde Mutasyon Analizi
}

${ }^{1}$ Gulcin Gunden, ${ }^{1}$ Sevgi Isik, ${ }^{2}$ Hava Uskudar Teke, ${ }^{1}$ Oguz Cilingir, ${ }^{2}$ Nur Oguz Davutoglu, ${ }^{1}$ Ebru Erzurumluoglu Gokalp, ${ }^{1}$ Sinem Kocagil, ${ }^{1}$ Sevilhan Artan, ${ }^{1}$ Beyhan Durak Aras

${ }^{1}$ Department of Medical Genetics, Faculty of Medicine, Eskisehir Osmangazi University, Eskisehir, Turkey

${ }^{2}$ Department of Hematology, Faculty of Medicine, Eskisehir Osmangazi University, Eskisehir, Turkey
Correspondence: Gülçin GÜNDEN

Department of Medical Genetics, Faculty of Medicine,

Eskisehir Osmangazi University, Eskisehir, Turkey

e-mail: gulcingunden2@gmail.com

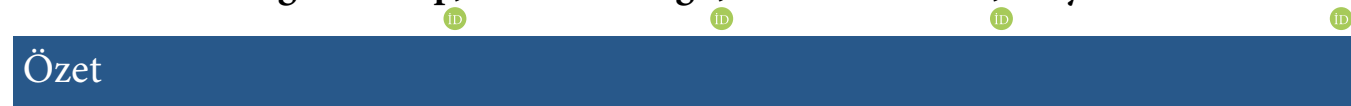

Kronik lenfositik lösemi (KLL) klonal matür B lenfositten kaynaklanan ve genetik heterojenite gösteren bir lösemi tipi olarak bilinmektedir. KLL’nin genomunun aydınlatılması için birçok çalışma yapıldığı görülmektedir. Bu çalışmalarda, kromozomal aberasyonlardan en sık del(13q)'nun meydana geldiği bildirilmektedir. Bu anomali izole olduğu durumda iyi prognoz ile ilişkilendirilmesine rağmen, hastalar klinik heterojenite göstermektedir. Bunun yanında kötü prognoz ile ilişkilendirilen TP53, NOTCH1 ve $S F 3 B 1$ gen mutasyonlarının da bulunduğu bir çok gende mutasyonlar tanımlanmış ve prognostik önemleri ortaya koyulmaya başlanmıştır. Biz de, bu veriler doğrultusunda FISH yöntemiyle izole del(13q) saptadığımız 43 olguda NOTCH1 ve SF3B1 genlerinin mutasyon oranını belirlemeyi ve prognoza (hastalık evreleri, TTFT ve OS) olan etkisini araştırmayı hedefledik. KLL'de en sık gözlenen $N O T C H 1$ ve SF3B1 gen mutasyonlarını Sanger sekanslama yöntemi ile araştırdık. Klinik heterojeniteye sahip KLL olgu grubumuzun, 1/42'sinde NOTCH1 geninde frameshift 7541_7542delCT mutasyonu saptanırken, SF3B1 geninde mutasyon tespit edemedik. Çalışmamız sonucunda, NOTCH1 ve SF3B1 gen mutasyonlarının literatür verileri ile uyumlu olarak izole del(13q) ile ilişkili olmadığı gözlenmiştir. Çalışmamız Türk populasyonunda izole del(13q) KLL hastalarında prognostik parametreler ile birlikte NOTCH1 ve SF3B1 gen mutasyonlarının değerlendirildiği ilk çalışma olma özelliğindedir. Sonuç olarak; izole del(13q) vakalarının klinik heterojenitesinden sorumlu başka nedenlerin de olabileceği ve bunların ortaya çıkarılmasını amaçlayan daha fazla çalışmaya ihtiyaç olduğu sonucuna varılmıştır.

Anahtar Kelimeler: Del13q; KLL; NOTCH1; Sanger; SF3B1

\section{Abstract}

Chronic lymphocytic leukemia (CLL) is known as type of leukemia originating from clonal mature B lymphocytes and has genetic heterogeneity. Many studies have been done to clarify the genome of CLL. In these studies, del(13q) is reported as the most common chromosomal aberration. Although this anomaly is associated with good prognosis when isolated, patients have clinical heterogeneity. In addition, in many gene mutations including TP53, NOTCH1 and SF3B1 gene mutations, poor prognosis has been identified. The prognostic significance of these genes has begun to be demonstrated. According to these data, we aimed to determine the mutation rate of NOTCH1 and SF3B1 genes and to investigate the prognostic effects (disease stages, TTFT and OS) in 43 cases with isolated del(13q) by using FISH method. We investigated the most common mutations of NOTCH1 and SF3B1 gene in CLL by using Sanger sequencing method. While frameshift 7541_7542delCT mutation was detected in the NOTCH1 gene in 1 out of 42 CLL cases with clinical heterogeneity, mutation in the SF3B1 gene couldn't be detected. As a result of our study, it was observed that NOTCH1 and SF3B1 gene mutations weren't associated with isolated del(13q) which is compatible with the literature data. Our study is the first study that evaluates NOTCH1 and SF3B1 gene mutations with prognostic parameters of isolated $\operatorname{del}(13 q)$ with CLL patients in the Turkish population. As a result; It was concluded that there may be different reasons responsible for the clinical heterogeneity of isolated $\operatorname{del}(13 \mathrm{q})$ cases and further studies are needed to reveal these reasons

Keywords: CLL; Del13q; NOTCH1; Sanger; SF3B1 


\section{Introduction}

Chronic lymphocytic leukemia is defined as CD5 + B cell malignancy (1). The effects of important genetic and epigenetic factors in the development of chronic lymphocytic leukemia have been revealed by further genome studies. In particular, the mutational status of the IGHV gene among these changes causes biological and clinical differences in CLL. While mutated-IGHV (MIGHV) is known as a good prognostic marker, unmutated-IGHV (UM-IGHV) is known as a poor prognostic marker. Recurrent cytogenetic anomalies usually occur in chronic lymphocytic leukemia. In $70-80 \%$ of the patients, these anomalies can be detected by FISH method. In chronic lymphocytic leukemia, trisomy of the chromosome 12, deletion of the short arm of the chromosome 17, deletions of the long arms of the chromosomes 13, 11 and 6 are defined as the most common chromosomal aberrations. These aberrations are prognostically important in CLL (2).

Deletions in the q14 site of the chromosome 13 (del(13q)) are known as the most common chromosome anomalies in CLL patients. In the literature, it is seen that $\operatorname{del}(13 q)$ is generally observed as the only cytogenetic anomaly in the early stages of the disease and is associated with good prognosis (3).

It is also stated that many gene mutations were detected in the genome of CLL and TP53, NOTCH1 and SF3B1 genes mutations were observed high frequency. It has also been emphasized that the mutational status of these genes has important effects on the pathogenesis and prognosis of CLL (4). Mutations in the NOTCH1 gene have been reported in $10 \%$ of the newly diagnosed CLL patients. NOTCH1 gene mutations were more common in patients with UM-IGHV CLL. In addition, a high frequency of this gene mutations have been reported $(40-50 \%)$ in CLL patients with trisomy 12 . NOTCHI gene mutations usually occur in the hotspot region of exon 34 in chronic lymphocytic leukemia, and these mutations have been reported to increase the aggressiveness of the disease. In addition, NOTCH1 gene mutations are often observed in advanced stages of the disease, causing the transformation of Richter Syndrome, they are also known to be associated with high relapse and therapy resistance. Heterozygous and missense mutations in the $S F 3 B 1$ gene were detected in $10 \%$ of CLL patients approximately, these mutations are associated with poor prognosis, and are frequently reported in the UMIGHV subtype of CLL (3).

After determining the importance of NOTCH1 and $S F 3 B 1$ gene mutations in CLL, many studies evaluated the relationship of these gene mutations with recurrent cytogenetic aberrations. According to the obtained data, it was concluded that the mutations of the relevant genes were associated with poor prognostic parameters and were accompanying chromosomal aberrations. In CLL cases with del(13q), which are known as most common aberration and are causing clinical heterogeneity, we aimed to examine the mutation profile of NOTCH1 and SF3B1 genes as well as the contribution of these mutations to heterogeneity.

\section{Material and Method}

\subsection{Material}

Our study includes 43 CLL cases with isolated $\operatorname{del}(13 \mathrm{q})$ detected by KLL FISH test (trisomy 12, del 17p, del11q and del13q). The cases were also previously evaluated for RB1 gene deletion by FISH method (5). The ages of the cases were between 43 and 89 (mean age: 70), 25 were women and 18 were men. DNA was obtained for the sanger sequencing study by using the Speed DNA isolation kit from the peripheral blood samples of the cases through applying the protocol suggested by the manufacturer.

This study was approved by the Clinical Practice Ethics Committee (2018-327). Also, signed consent forms were received from all patients.

\subsection{Method}

In the NOTCH1 gene, to detect 7541_7542delCT and 7444delC mutations, the PEST domain in exon 34 was sequenced using 5 'TTGGCGTGAGCTCAGCAGCC 3 ' as the forward primer and 5 'AAAAAGGCTCCTCTGGTCGG 3 as the reverse primer. Exons 14, 15 and 16 changes of SF3B1 gene to detect pathogenic nucleotide changes $(2098 \mathrm{~A}>\mathrm{G}, 1866 \mathrm{G}>\mathrm{T}, 1998 \mathrm{G}>\mathrm{T}$ and 2225 G $>$ A) was sequenced using 5'CGAGAGATCATTTCTAATTT $3^{\prime}$ as the forward primer and 5'CGAATAAGGATTAACATCAC $3^{\prime}$ as the reverse primer. The mutations of the relevant genes were scanned according to the protocol of 
the Sanger sequencing method. The obtained data were analyzed in SeqScape program. In addition, the settings, according to Applied Biosystem Genetic Analyzer with Data Collection Software v2.0, were made in order for the prepare the device for proper reading.

\section{Results}

When we evaluated some clinical data of 43 isolated del(13q) CLL cases in our study; clinical heterogeneity in terms of disease stages, time to first treatment (TTFT) and overall survival (OS) prognostic parameters were detected (Table 1). In our study, in order to investigate the effect of NOTCH1 and SF3B1 mutations of this heterogeneity; The del(13q) ratio of $67 \%$ of our cases was above $70 \%$, and the $\operatorname{del}(13 q)$ ratio of the remaining cases was below $70 \% .39$ of the cases were evaluated in terms of $R B 1$ gene deletion, and $R B 1$ gene deletion was detected in $24 \%$ of the cases. 35 of the cases reached OS information and out of these cases 3 died. We were able to obtain information about whether 33 of the 43 cases received treatment or not. We found that $43 \%$ of 33 cases had received treatment. In addition, according to the disease stage information of the same cases; 29\% (RAI III and IV) are advanced stage, 71\% (RAI 0, I and II) are early stage. Frameshift 7541 7542delCT mutation was detected in the NOTCH1 gene in $1 / 42$ of the case group with clinical heterogeneity (Figure 1). The case with mutation in the relevant gene reaches part II stage in the RAI staging system and the TTFT of the case is the 6th month. In addition, it has been observed that del(13q) ratio was $>80 \%$ and RB1 gene deletion was found in the case. Mutational status of SF3BI gene could be evaluated in 39 cases. However, hotspot mutations of the related gene weren't detected in any of our cases. According to the obtained data in the isolated del(13q) case group, a statistical evaluation couldn't be made do due to the low rate of NOTCHI and SF3B1 mutations.

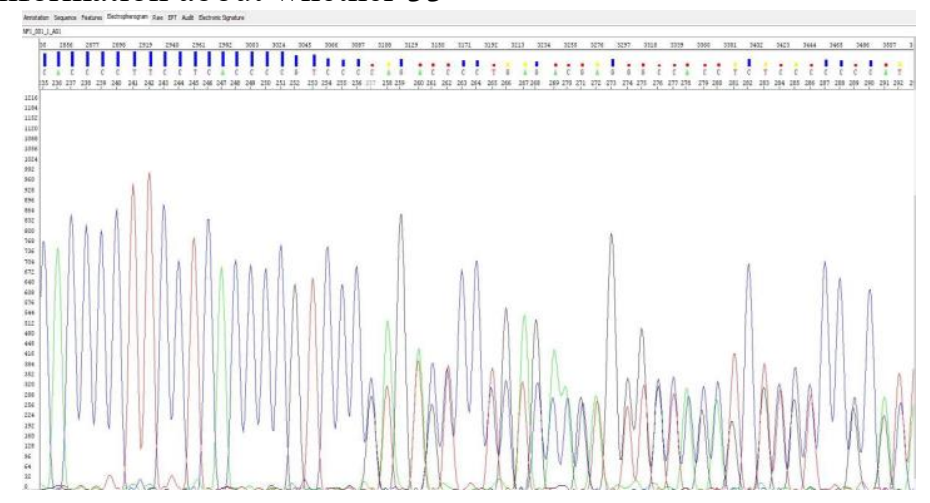

Figure 1.7541_7542delCT mutation in NOTCH1

Table 1. Association of isolated $13 \mathrm{q}$ deletion with prognostic markers and molecular characteristics of CLL patients

\begin{tabular}{|c|c|}
\hline T & Isolated $\cdot$ dell3q'(43)a \\
\hline \multicolumn{2}{|l|}{ a } \\
\hline Agea & $70 \cdot(43-89) a$ \\
\hline \multicolumn{2}{|l|}{ RAI-stage'x } \\
\hline 0,I·and $\cdot I I a$ & 210 \\
\hline III'and $\cdot$ IV $x$ & 110 \\
\hline \multicolumn{2}{|l|}{$\mathrm{OSa}$} \\
\hline Live $(1-176 \cdot$ months $) \alpha$ & $32 \alpha$ \\
\hline Alived & 30 \\
\hline Treatmento & 150 \\
\hline Non-treatmento & 180 \\
\hline Dell3q ratio $>\% 70$ & 29 \\
\hline$\ldots \ldots+\cdots \cdots$ & $24 \alpha$ \\
\hline DelRBla & 100 \\
\hline Non-delRBla & $23 \alpha$ \\
\hline SF3B1-mutationso & 00 \\
\hline $\begin{array}{l}\text { NOTCHl- } \\
\text { mutationso }\end{array}$ & 10 \\
\hline
\end{tabular}




\section{Discussion}

CLL patients with isolated 13q deletion have better prognosis than CLL patients with nonisolated del(13q). However, it is known that CLL patients with isolated del(13q) have heterogeneity in terms of prognosis (OS, TTFT) (6). It is suggested that the reason behind this heterogeneity, may be the size of the $13 q$ deletion, deletion rate and additional gene mutations.

NOTCH1 and SF3B1 gene mutations have been revealed to unfavourably affect the prognosis of CLL, and these gene mutations are associated with advanced RAI / Binet stages and short TTFT and OS $(7,8)$ In the study, we aimed to investigate the role of $N O T C H 1$ and $S F 3 B 1$ gene mutations in the isolated $\operatorname{del}(13 \mathrm{q})$ cases with clinical heterogeneity, we only found mutation in one case. According to these data, it was concluded that in CLL cases with del13q there were a quite low frequency of NOTCH1 and SF3B1 gene mutations.

Miao et al. grouped 323 cases with untreated CLL as isolated del(13q) anomaly or non-isolated del13q, also del(13q) rates have been grouped > $80 \%$ and $<80 \%$. As a result of their study, they found NOTCH1 gene mutation rate was $12.9 \%$ in cases with non-isolated $\operatorname{del}(13 q)$ and $1.6 \%(1 / 61)$ in cases with isolated del(13q). In addition, the rate of mutation detected in the $S F 3 B 1$ gene in cases with non-isolated $13 \mathrm{q}$ deletion was reported as $0 \%$ and the rate of mutation in the relevant gene in isolated $\operatorname{del}(13 q)$ cases was reported as $4.8 \%$. The researchers stated that the mutations of the genes were associated with high del(13q) ratio (> 80\%) (6). Although the deletion rate of $13 \mathrm{q}$ was $>80 \%$ in the case with detected NOTCHI gene mutation, no mutation was detected in the other 9 cases with $>80 \%$ deletion rate. However, it shouldn't be ignored that we only analyzed hotspot regions. Baliakas et al. reported a positive relationship between NOTCH1 gene mutation and advanced stage and trisomy 12 , and a negative relationship with isolated del(13q) as a result of their study with 3490 CLL patients. As a result of the same study, they found that $S F 3 B 1$ gene mutations was positively correlated with del11q and advanced stage cases, and negatively correlated with trisomy 12 and isolated del(13q) (9). SF3B1 gene mutations were detected in 6 patients with deletion 13q14 in their study of 545 CLL patients by Schwaederle et al. and no relationship between $S F 3 B 1$ gene mutations and del(13q) was reported (10).

As a result of their study with 1124 newly diagnosed CLL patients, Jeromin et al. reported that $S F 3 B 1$ gene mutation was more frequent in del11q and isolated del(13q) chromosome anomalies compared to other chromosomal anomalies. They reported that $S F 3 B 1$ gene mutations had a poor prognostic effect in CLL patients with isolated del(13q) (11). Villamor et al. detected del(13q) in 47 of the 565 CLL cases in their study and they used whole exome sequencing (WES) and whole genome sequencing (WGS) methods. They stated that the NOTCH1 gene was mutated in $29 \%$ of the CLL patients with del(13q) and with advanced disease stage. They also reported that NOTCH1 gene mutations were associated with short survival, independently of the mutational status of IGHV (12). $\mathrm{Xu}$ et al. reported that NOTCH1 gene mutations were associated with $\operatorname{del}(13 \mathrm{q})$ and trisomy 12 (13).

According to all these data, it is observed that NOTCH1 and SF3B1 gene mutations are associated with poor prognostic markers in CLL, and also their frequency is low in the isolated del (13q) group of CLL with good prognostic feature. But some studies indicate the opposite which are also included in the literature.

One of the reasons of the mutation rates in our study may be the analysis of the hotspot regions. Perez et al. reported that although del(13q) was considered good prognostic in CLL cases, this prognosis can be varied. They detected $10.3 \%$ TP53, 9.4\% NOTCH1, 8.6\% SF3B1, 5.1\% ATM and $3.4 \%$ BIRC3 gene mutations in 73 treatmentresistant CLL cases with del(13q). Even if, they stated that $63 \%$ of the isolated $\operatorname{del}(13 q)$ patients had more than one mutation (14). This suggests that other gene mutations may have an effect on the clinical heterogeneity of isolated $\operatorname{del}(13 q)$ CLL cases.

According to the points that are addressed in the literature, the data in our study are thought to be remarkable in terms of being the first data belonging to the Turkish population. As a result, we think that more studies involving more cases are needed to clarify the reason for the clinical heterogeneity of isolated del (13q) CLL cases associated with good prognostic effect in order to explain the effect of $N O T C H 1$ and $S F 3 B 1$ gene mutations. 
- İzole Dell3q Kronik Lenfositik Lösemi Olgularında NOTCH1 ve SF3B1 Genlerinin
Mutasyonel Durumu. Online 14. Ulusal Tibbi Genetik Kongresi. (20-22 Kasım 2020)

\section{REFERENCES}

1. Kipps TJ, Stevenson FK, Wu CJ, Croce CM, Packham G, Wierda WG, et al. Chronic lymphocytic leukaemia. Nat Rev Dis Primers. 2017;3:16096.

2. Jiang Y, Chen HC, Su X, Thompson PA, Liu X, Do KA, et al. ATM function and its relationship with ATM gene mutations in chronic lymphocytic leukemia with the recurrent deletion (11q22.3-23.2). Blood Cancer $J$ 2016;6:e465.

3. Fabbri G, Dalla-Favera R. The molecular pathogenesis of chronic lymphocytic leukaemia. Nat Rev Cancer. 2016;16:145-62.

4. Tausch E, Beck P, Schlenk RF, Jebaraj BJ, Dolnik A, Yosifov DY, et al. Prognostic and predictive role of gene mutations in chronic lymphocytic leukemia: results from the pivotal phase III study Complement1. Haematologica. 2020;105:2440-7.

5. Durak Aras B, Isik S, Uskudar Teke H, Aslan A, Yavasoglu F, Gulbas Z, et al. Which prognostic marker is responsible for the clinical heterogeneity in CLL with 13q deletion? Mol Cytogenet. 2021;14:2.

6. Miao Y, Miao Y, Shi K, Sun Q, Zhao SS, Xia Y, et al. A higher percentage of cells with $13 \mathrm{q}$ deletion predicts worse outcome in Chinese patients with chronic lymphocytic leukemia carrying isolated 13q deletion. Ann Hematol. 2018;97:1663-9.

7. Hu B, Patel KP, Chen HC, Wang X, Luthra R, Routbort $\mathrm{MJ}$, et al. Association of gene mutations with time-to-first treatment in 384 treatment-naive chronic lymphocytic leukaemia patients. Br J Haematol. 2019;187:307-18.

8. Oscier DG, Rose-Zerilli MJ, Winkelmann N, Gonzalez de Castro D, Gomez B, Forster J, et al. The clinical significance of NOTCH1 and SF3B1 mutations in the UK LRF CLL4 trial. Blood. 2013;121:468-75.

9. Baliakas P, Hadzidimitriou A, Sutton LA, Rossi D, Minga E, Villamor N, et al. Recurrent mutations refine prognosis in chronic lymphocytic leukemia. Leukemia. 2015;29:32936.

10. Schwaederlé M, Ghia E, Rassenti LZ, Obara M, Dell'Aquila ML, Fecteau JF, et al. Subclonal evolution involving SF3B1 mutations in chronic lymphocytic leukemia. Leukemia. 2013;27:1214-7.

11. Jeromin S, Weissmann S, Haferlach C, Dicker F, Bayer K, Grossmann V, et al. SF3B1 mutations correlated to cytogenetics and mutations in NOTCH1, FBXW7, MYD88, XPO1 and TP53 in 1160 untreated CLL patients. Leukemia. 2014;28:108-17.

12. Villamor N, Conde L, Martínez-Trillos A, Cazorla M, Navarro A, Beà $\mathrm{S}$, et al. NOTCH1 mutations identify a genetic subgroup of chronic lymphocytic leukemia patients with high risk of transformation and poor outcome. Leukemia. 2013;27:1100-6.

13. Xu ZS, Zhang JS, Zhang JY, Wu SQ, Xiong DL, Chen HJ, et al. Constitutive activation of NF- $\mathrm{NB}$ signaling by NOTCH1 mutations in chronic lymphocytic leukemia Oncol Rep. 2015;33(4):1609-14.

14. Pérez C. C. R-VEA, Hernández-Sánchez M., QuijadaÁlamo M., Benito R., Hernández-Sánchez J., MartínIzquierdo M. \& \& Hernández Rivas J. Notch1, Tp53, Sf3b1, Atm And Bırc3 Gene Mutations Are Associated With A Worse Outcome In Chronic Lymphocytic Leukemia Patients With 13q Losses. European Hematology Association 2018. 